\title{
Job hazard analysis in the killing area of a federal inspection slaughterhouse
}

\author{
Análisis de riesgos de trabajo en área de sacrificio de un rastro tipo inspección \\ federal
}

CANO-CARRASCO, Adolfot, VÁSQUEZ-TORRES, María del Carmen, FORNÉS-RIVERA René Daniel and VELDERRAIN-JACOBO José Alberto

Instituto Tecnológico de Sonora, Mexico.

ID $1^{\text {st }}$ Author: Adolfo, Cano-Carrasco / ORC ID: 0000-0002-3392-3667, Researcher ID Thomson: G-5035-2018, arXiv ID Author: adolfo.cano, CVU CONACYT ID: 266064

ID $1^{\text {st }}$ Coauthor: María del Carmen, Vásquez-Torres / ORC ID: 0000-0003-0938-4955, Researcher ID Thomson: X-21042018, CVU CONACYT ID: 286266

ID $2^{\text {nd }}$ Coauthor: René Daniel, Fornés-Rivera / ORC ID: 0000-0002-7438-0056, Researcher ID Thomson: G-3906-2018, arXiv ID Author: rene_fornes, CVU CONACYT ID: 280435

ID $3^{\text {rd }}$ Coauthor: José Alberto, Velderrain-Jacobo / ORC ID: 0000-0002-3567- 3788, arXiv ID Author: josevelderrain

DOI: $10.35429 / J L D E .2020 .6 .4 .9 .15$

Received January 15, 2020; Accepted June 30, 2020

\begin{abstract}
This research deals with occupational safety and health and its scope includes the conditions in which the worker must perform his tasks, the hazards to which the worker is exposed, their prevention and control. The study object is the killing area of a TIF slaughterhouse which handles the problem of reducing the number of accidents that jeopardizes the integrity of workers. The objective was to reduce the risk of the worker reflected in the number of accidents. The procedure was to Identify risks and threats in the work area, Analyze risks at work stations. Risk assessment and proposal development. The results show the risks present in the killing area in which the use of PPE is a common and most critical cause, an in-depth analysis reveals that the problem is common to the other areas, of a total of 326 incidents killing has a value of 49 and $89 \%$ of these incidents have a high probability of causing temporary loss of working capacity impacting directly to the risk premium, only $11 \%$ could cause permanent partial disability. Finally, after carrying out an inspection program, the partial result in number of accidents at the end of this research was 4 compared to the previous year with 10 .
\end{abstract}

Risk, Meat industry, Safety and occupational health

\begin{abstract}
Resumen
Esta investigación versa sobre la seguridad y salud en el trabajo y su ámbito incluye las condiciones en las que el trabajador debe desempeñar sus tareas, los riesgos a los que el trabajador está expuesto, su prevención y control. El objeto de estudio es el área de Sacrificio de un rastro TIF en el cual se aborda el problema de reducir la cantidad de accidentes que pone en riesgo la integridad de los trabajadores. Se fijó como objetivo reducir el riesgo del trabajador reflejado en la cantidad de accidentes. El procedimiento fue identificar riesgos y amenazas en el área de trabajo, Analizar riesgos en estaciones de trabajo. Evaluación del riesgo y Desarrollo de propuestas. Los resultados muestran los riesgos presentes en el área de Sacrificio en los cuales el uso de EPP es una causa común y la más crítica, un análisis en profundidad revela que el problema es común a las demás áreas, de un total de 326 incidencias Sacrificio presenta un valor de 49 y el $89 \%$ de dichas incidencias tienen alta probabilidad de causar días de incapacidad impactando directamente a la prima de riesgo, solo un $11 \%$ podría causar incapacidad parcial permanente. Finalmente, después de realizado un programa de inspecciones el resultado parcial en número de accidentes al finalizar esta investigación fue de 4 comparado con el año anterior de 10 .
\end{abstract}

Riesgo, Industria cárnica, Seguridad y Salud ocupacional

Citation: CANO-CARRASCO, Adolfo, VÁSQUEZ-TORRES, María del Carmen, FORNÉS-RIVERA René Daniel and VELDERRAIN-JACOBO José Alberto. Job hazard analysis in the killing area of a federal inspection slaughterhouse. JournalLabor and Demographic economic. 2020. 4-6:9-15.

\footnotetext{
$\dagger$ Researcher contributing first author.
} 


\section{Introduction}

The meat sector of the food processing industry is engaged in the production of beef, poultry, pork and other edible animals through farming, fattening, processing and packaging activities. In Mexico, the states of Veracruz and Jalisco stand out in the national production of meat in beef and chicken, as well as the case of Jalisco and Sonora, which are leaders in pork (Haro, 2019).

According to data provided in Graphic 1 and 2 by the Mexican Meat Council (Bazán, 2018), the distribution of personnel working in the meat industry consists in 2018 with 18,339 in the killing area, 11,377 in cutting and packaging, 39,692 in sausages, making up a total of 69,407 in the meat sector.

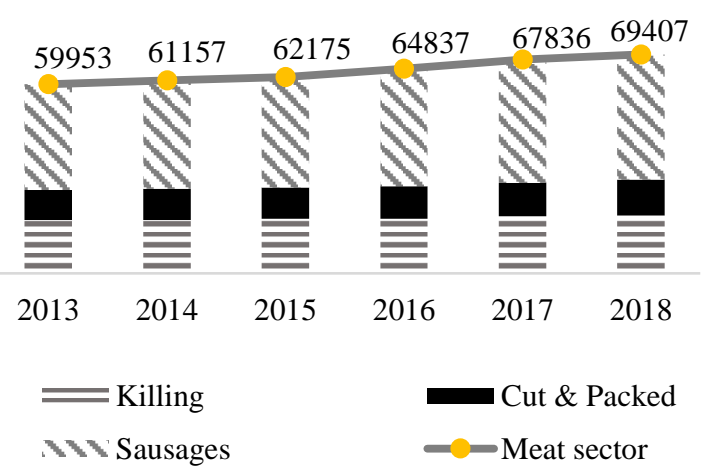

Graphic 1 Personnel working in the meat sector

The percentage of distribution of personnel in the areas that make up the meat sector can be seen in Graphic 2.

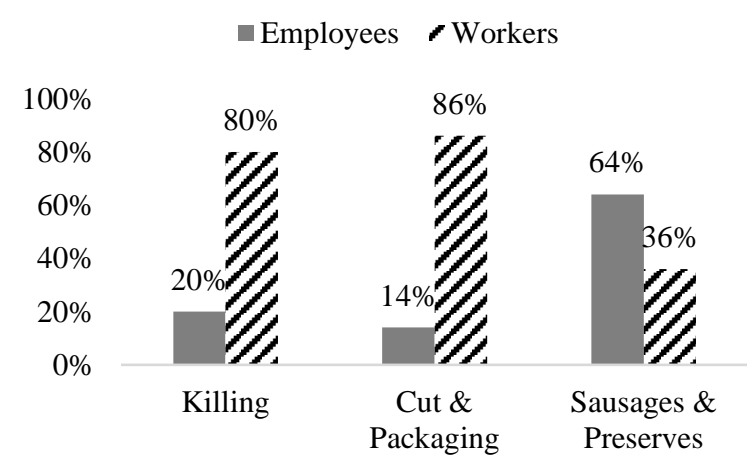

Graphic 2 Percentage distribution of personnel in the meat sector in Mexico as of 2018

The number of accidents in the workplace of the meat industry is not as high as in others, the lack of training in prevention in workers is the main cause of accidents, hence these risks can be mitigated with appropriate measures within the Occupational Risk Prevention Plan (PREVEN SYSTEM, 2017).
The risk map in this meat sector includes risks of entrapment by machine, projections, cuts and blows, work in confined space, accidents by explosion, fire, electrical, chemical, biological, vibrations, Overexertion and physical load, thermal stress due to cold, noise, excessive workload (UGT, 2007).

Frequently, work accidents occur due to unsafe conditions that exist in equipment, machines, work tools and facilities, as well as the unsafe attitude or acts of workers when carrying out activities. Other causes of work accidents may be associated with dangerous conditions such as wrong work methods and work procedures, damage to equipment, machinery, work tools and facilities, incorrect placement of materials or products in work areas, machinery and tools in poor condition, facilities with poor maintenance, lack of order and cleanliness in work areas. (IMSS, 2017)

They can also be generated by unsafe acts such as causing risky situations that put people in danger by using the hands or other parts of the body in an inappropriate way, carrying out activities or operations without prior killing, operating equipment without authorization, cleaning, oiling or repair machinery when it is in motion, do not use personal protective equipment (IMSS, 2017).

The company in which this project is developed is a Federal Inspection Type (TIF) slaughterhouse, where pork is processed for national and international sale. The TIF slaughterhouse are facilities for the slaughter, processing and sanitary industrialization of beef, pork and poultry (FIRCO, 2016).

The production plant is divided into three areas: killing, Cutting and added value. And they manufacture six main cuts of which a variety of products are generated that are exported to Japan, these products generate most of the monetary income to the company. From these six cuts there are other secondary cuts which are sold in the national market. The description of the company's production process is shown below in a process diagram see Figure 1. 


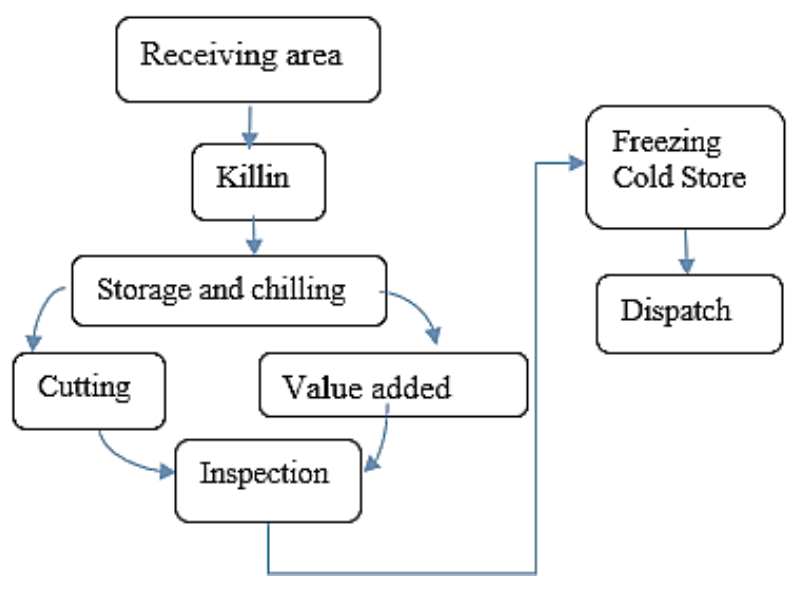

Figure 1 Process diagram of the company under study Source: Vázquez and López, (2013)

The process begins (Verdugo, 2014) with the arrival of the raw material to pens in trucks that bring approximately 200 pigs per truck, from here they are stored for a day and later they are taken to the slaughter room. Once in the slaughter area, the pig is bled to later pass to the processing of the carcass, this process lasts approximately 20 minutes. Carcass processing consists of shaving and gutting, then they are stored in refrigeration cabinets that are between $0{ }^{\circ} \mathrm{C}$ to $4^{\circ} \mathrm{C}$ and are stored for 17 to 41 hours. Throughout the slaughter process there are quality stations where the pig is checked for disease and that quality standards are met. Once the pork carcasses reach temperature, they are called cold carcasses and are taken to the cutting room where the relevant cuts and details are made to generate by-products and export products.

Some cut products are the value-added raw material where other types of meat processes are carried out and the product is detailed depending on the client's specifications. Products from both areas are inspected to see that they meet the requirements and are packaged to be taken to the finished product warehouse and shipped.

This research deals with health and safety at work and its scope includes the conditions in which the worker must perform their tasks and the risks to which the worker is exposed, the ways to prevent it, the use of personal protective equipment and the fulfillment of the norms of this nature that establish the organisms that accredit to the trace and the company by itself. The monitoring indicators in the company's industrial safety department are shown in Table 1.

\begin{tabular}{|l|r|r|r|r|}
\hline Accidents per year & 78 & 2016 & 2017 & \multicolumn{2}{|c|}{2018} \\
\hline $\begin{array}{l}\text { Days of disability per } \\
\text { year }\end{array}$ & 1694 & 1470 & 1286 & Unknown \\
\hline Permanent disability & 0 & 0 & 0 & 0 \\
\hline
\end{tabular}

Table 1 Historical values of industrial safety indicators in the company under study

As can be seen in Table 1, the number of accidents in 2017 is higher than in 2015 and slightly lower than in 2016. According to the company's safety officer, these indicators have increased since past years and no action has been taken to reduce its value.

The development of dangerous activities without protection leaves the workers exposed and potentiates labor affectations Currently operations in the killing area are carried out without supervision, as a control measure to ensure the use of personal protective equipment and as a measure to prevent the occurrence of acts unsafe by employees.

The area under study is the killing area, which due to the nature of its operations is the most critical. The behavior of the safety and hygiene monitoring indicators in the Slaughter area is shown in Table 2.

\begin{tabular}{|l|r|r|r|r|}
\hline & $\mathbf{2 0 1 5}$ & $\mathbf{2 0 1 6}$ & $\mathbf{2 0 1 7}$ & $\mathbf{2 0 1 8}$ \\
\hline Accidents per year & 20 & 30 & 10 & 4 \\
\hline $\begin{array}{l}\text { Days of disability per } \\
\text { year }\end{array}$ & 151 & 110 & 49 & 18 \\
\hline Permanent disability & 0 & 0 & 0 & 0 \\
\hline
\end{tabular}

Table 2 Historical values of industrial safety indicators in the killing area

The number of work accidents in the killing area presents relevant values that impact on extra expenses for days of incapacity for work and increases in the annual risk premium. Therefore, the following problem arises:

"The number of accidents in the Killing area of the Federal Inspection Slaughterhouse puts the integrity of the workers and the continuity of operations in the company under study at risk"

\section{Objective}

Therefore the objective is expressed as. 
Reduce the number of work accidents that endanger the integrity of workers in the Killing area of the Federal Inspection Slaughterhouse, through compliance with safety regulations.

\section{Theoretical framework}

Systems are necessary in organizations and one of these is for the application of safety and health standards. Unfortunately, the effort required by the administration to guarantee the operation of a health and safety prevention system is not always considered a priority when more urgent problems arise (Pain, 2018). Despite all the progress, we still kill people at work. According to recent estimates published by the International Labor Organization (ILO, 2019), 2.78 million workers die each year from occupational accidents and diseases (of which 2.4 million are related to diseases) and 374 million workers suffer non-fatal work accidents.

Frequently, only after an accident occurs, the investigating team returns to the safety instructions and finds to their relief that some control procedure has been violated, the leaders of the organization will feel relieved and the affected will have a summary of the case. It may seem a bit ironic, but it is not far from reality, the reflection is the organization has failed in its task of guaranteeing compliance with the security procedure (Asbury, 2018) and Pain (2018).

The Secretary of Labor and Social Welfare defines the danger as the characteristics or intrinsic properties of the agents or conditions present in the work environment. Its degree of danger is obtained by evaluating the potentiality of the effect that these characteristics or properties of the agents or conditions can generate or provoke, on the other hand, the work risk is represented by the correlation of the dangerousness of an agent or physical condition and the exposure of workers with the possibility of causing adverse effects on their health or life, or damaging the workplace. As an expression, the risk equals the danger from the worker's exposure. (STPS, 2009).
It is the employer's obligation to provide the means and facilities to establish safety and health measures at work for the prevention of accidents and occupational diseases. Also, among other attributions, it is a requirement for the employer to incorporate in the occupational health and safety program or in the list of preventive and corrective actions for occupational health and safety, actions and promotion programs for workers' health. and for the comprehensive prevention of addictions recommended or dictated by the competent authorities (STPS, 2009).

Hazard recognition is focused on identifying perceived, existing and potential hazards and / or consequences of exposure to hazards and a fundamental task of a hazard recognition system is to help management and employees to become aware of the hazards. operational hazards and associated risks. This knowledge is essential to ensure that hazards are controlled, reduced, or eliminated as they are identified (Roughton \& Crutchfield, 2008).

In general terms, the process for systematic risk assessment and analysis includes the following activities (1) Conduct a workplace risk assessment (2) Prioritize the results of the risk assessment (3) Development of controls to solve problems risk-related (4) Recommend and implement controls (5) Follow-up of the results of implemented controls (Roughton \& Crutchfield, 2008). The risks in a slaughter area are very frequent, as expressed by González, Casique and López (2015) in a study carried out in a slaughterhouse in the Guanajuato region, which confirms the fact that the causes of work accidents focus on poor safety and hygiene conditions by not having the necessary instruments and tools or by the existence of poor conditions, coupled with the lack of personal protective equipment and excessive workloads requiring physical effort, causing absenteeism and turnover of personal. Likewise, the most frequent damage to health detected consists of cuts, injuries and fractures caused by the use of sharp objects and handling of heavy loads. 


\section{Methodology to be developed}

The selected Procedure is based on the Job Hazard Analysis (JHA) by Roughton \& Crutchfield (2008) in which it describes how to evaluate possible risks, understand the consequences of the risk, and act to help identify, eliminate or control hazards. The following steps were used.

(1) Identify risks and threats in the work area. For this purpose, tours of the company's killing area were made and the personnel working there were interviewed to obtain information regarding risks. With the help of industrial safety formats provided by the company and based on the criteria of the NOM's applicable to the company and the area under study, observations were made, which consist of a list of the area risks classified by type and a risk map of the killing area. (2) Analyze risks at workstations. A process FMEA was carried out to identify the importance of risks and their causes. Then, an operation monitoring program was implemented in the main areas that cover the organization's processes, with the intention of understanding the nature of incidents and work accidents that occurred during a set period of time. (3) Risk assessment. Once the causes had been identified, the evaluation was made based on the risk matrix adapted from NOM-031STPS-2011 (STPS, 2011) based on two probability criteria of Occurrence and Impact. The probability scale contemplates Remote, Isolated, Occasional, Recurrent and Frequent occurrence with values from 1 to 5 correspondingly. On the other hand, the impact was valued as Minor, Moderate, Critical, Fatal with values ranging from 1 to 4 correspondingly, and the assessment of the level of risk was Minimal in that which is managed through routine and / or process, Low that requires constant monitoring and detection plans, Medium that requires senior management attention and preventive plans, High requires immediate action and an action plan and Serious requires immediate attention in order to modify the security conditions; the safety instructions; personal protective equipment, or training. (4) Development of proposals. With the results obtained from the analysis and risk assessment, an action plan was carried out to prevent the recurrence of accidents and prevent work risks.

\section{Results}

The risks identified from the visual inspections in the killing area were graphically represented on a risk map, which is shown in Figure 2 below.

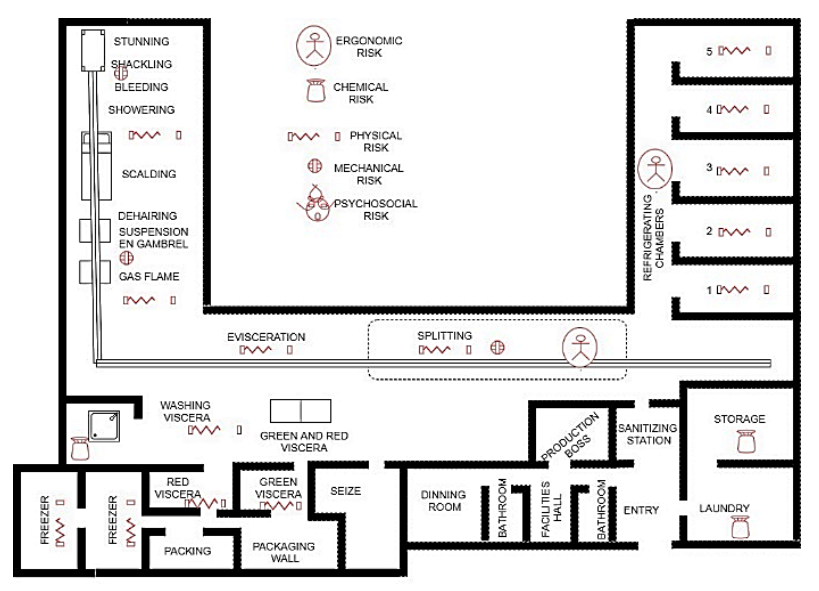

Figure 2 Risk map of the killing area

A detailed description of the risk factors identified in the risk map presented in Figure 2 is shown below.

Physical risk factors:

- $\quad$ Excessive noise in the killing room (above a constant $98 \mathrm{~dB}$. Use of earplugs (leaving the use at the discretion of the worker).

Temp. $40^{\circ} \mathrm{C}$ in summer. Use of fans from canal chambers (freezers) to killing area.

- Wet floor. The mandatory use of anti-slip sanitary boots is a policy.

- Steam pipes at $80{ }^{\circ} \mathrm{C}$ in walls and personnel flow areas. There is no control measure.

- Frozen soil in gutter chambers and freezers. Countermeasures are lacking.

Regarding Chemical Substances:

- Contact with organic matter, pork gastric juices and chlorinated water. Latex gloves and plastic sleeves are used to avoid contact (at the discretion of the worker).

- Use of acid to wash rolls. Latex gloves and plastic sleeves are used to avoid contact (at the discretion of the worker). 
The Mechanical factors were:

- Work stations on elevated platforms without handrails. There is no countermeasure.

- Machinery in the room is continually failing. There is no countermeasure.

Handling of sharp objects by most of the staff. Anti cut gloves are used (mandatory when using a knife).

Danger of impact from pigs hanging in motion. Use of helmet (mandatory).

Regarding Ergonomic factors:

Strong constant vibration in electric saw station. No countermeasures.

Transfer of pigs by rails without motorization. Excessive exertion. Use of lumbar girdle.

Table 3 shows the following the risks identified through the process sequence (workstations) and the level indicator qualified of minimum, low, medium, high, and severe, corresponding to the colors blue, green, yellow, orange and red.

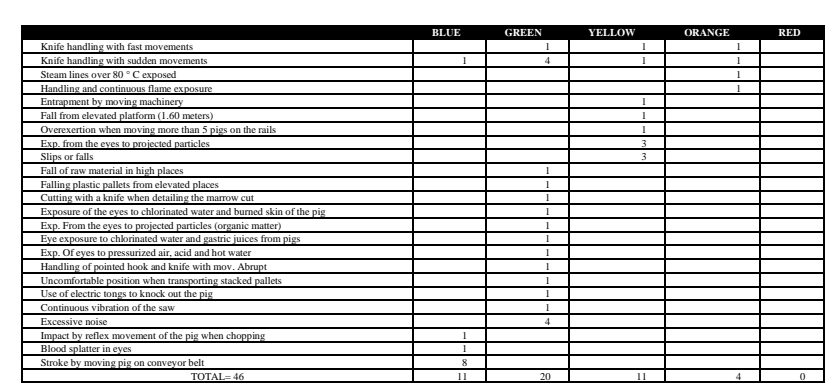

Table 3 Causes of risk and priority level

The causes associated with the risks are those shown in Graphic 3. In which the left axis shows the accumulated evaluation of the risk priority number (RPN).

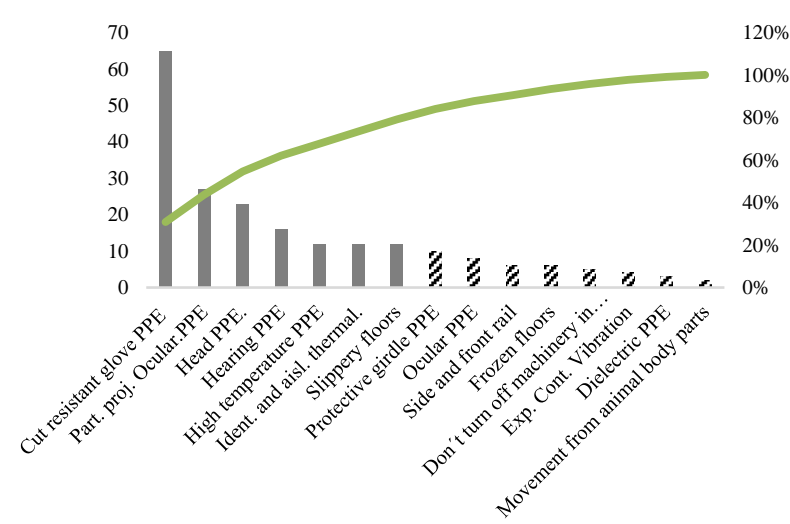

Graphic 3 Prioritization of causes of risk in the Killing area

It can be seen that the main causes of accidents are represented by the lack of Personal Protective Equipment (PPE) for Hands, Ocular, Head, Hearing, High.

Temperatures; also to the identification of thermal pipe insulation and slippery floors.

Because the main cause of the problem is the non-use of PPE, a general study was carried out to visualize incidents in the main areas of the organization, in which it is evident that the Value Added, Shipping, Killing and Cutting area present high level of incidents in the use of PPE see Graphic 4.

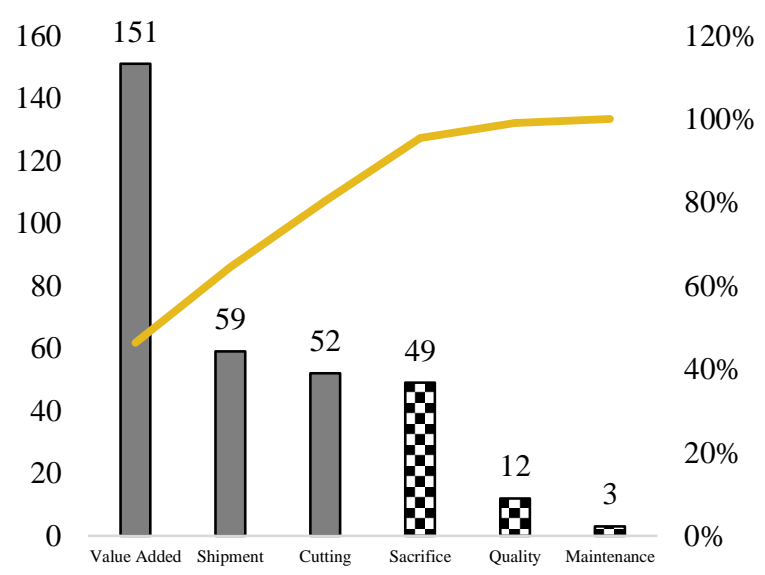

Graphic 4 Number of incidents by area in use of PPE

Out of a total of 326 Killing incidents, there is a value of 49 . And $89 \%$ of these incidents have a high probability of causing days of disability, directly impacting the risk premium and only $11 \%$ could cause permanent partial disability, finally after it This inspection program the partial result in number of accidents at the end of this investigation was 4 compared to the previous year of 10 . 


\section{Conclusions}

Although it is important to continuously apply the Job Hazard Analysis, its systematization will reflect the degree of maturity that the organization has in the implementation of a risk prevention system.

Its application is recommended in situations where the risk is known due to records of injuries or disabilities, in tasks that involve serious injuries even when these are not yet present, in new tasks and in non-routine work and in modified or relocated processes.

Operating through a continuous verification program will allow the timely identification of unsafe acts and unsafe conditions, the promotion of the use of mandatory PPE in work areas during the execution of operations, as well as the establishment of a risk prevention policy that establishes the participation of employees in reporting hazards, the continuous selfassessment of the risk prevention system complemented with the audit to identify deficiencies at the level of the support areas in charge of identifying the level of skills and knowledge consistent with the job, such as Recruitment of personnel and Training, together all these actions will contribute to making the operation of the TIF Slaughterhouse more efficient, giving a timely response to the identified risks.

\section{References}

Asbury S. (2018). Health and safety Environment and Quality Audits, A Risk based Approach, 3er ed. Taylor \& Francis Group.

Bazán H. N., (2018). Consejo Mexicano de la Carne. Compendio estadístico. Gerencia de estudios económicos y comercio exterior. Recuperado de: https://comecarne.org

FIRCO (2016). ¿Sabes que es un Rastro Tipo Inspección Federal?, recuperado de: https://www.gob.mx/firco/, mayo 2020.

González R. M., Casique G. A., López C.F, (2015). Estudio de riesgos de trabajo en el rastro municipal Tarimoro, Guanajuato. Revista RAITES (antes Panorama Administrativo).
Haro L.F., (2019). Importancia de la industria cárnica en México. Ing. Luis Fernando Haro Encinas, Director General del Consejo Nacional Agropecuario. INFORURAL. Recuperado de: https://www.elsoldemexico.com.mx

IMSS, (2017). Prevención de Accidentes en el Trabajo. Recuperado de: http://www.imss.gob.mx/, mayo 2020.

OIT (2019) ILO-OSH 2001 Seguridad y Salud en el centro del futuro del trabajo. Aprovechar 100 años de experiencia. Oficina Internacional del Trabajo.

PREVEN SYSTEM, (2017). Riesgos laborales en elaboración de productos cárnicos. Recuperado de: http://www.prevensystem.com/

Pain S. W. (2018). Safety, Health and Environmental Auditing. A Practical Guide, Second Edition CRC Press. Taylor \& Francis Group.

Roughton, J. E., \& Crutchfield, N. (2008). Job Hazard Analysis. A Guide for Voluntary Compliance and Beyond. Burlington, MA: Elsevier.

STPS, (2011). NORMA Oficial Mexicana NOM-031-STPS-2009, Servicios preventivos de seguridad y salud en el trabajo-Funciones y actividades.

STPS, (2009). NORMA Oficial Mexicana NOM-030-STPS-2009, Servicios preventivos de seguridad y salud en el trabajo-Funciones y actividades.

UGT, (2007). Guía Prevención de Riesgos Psicosociales en la Industria Cárnica. Observatorio permanente de riesgos psicosociales. Unión General de Trabajadores. Comisión Ejecutiva Confederal UGT. Madrid. Recuperado de: http://portal.ugt.org/

Verdugo, A. R. (2014). Aumento de rendimiento cárnico en las salas de corte y sacrificio de una empresa de giro agroindustrial. Obregón: ITSON.

Vázquez, J. A., y López, D. A. (2013). Reducción de desperdicio cárnico en las. Obregón: ITSON. 